\title{
Corrigendum: The Resistome of Farmed Fish Feces Contributes to the Enrichment of Antibiotic Resistance Genes in Sediments below Baltic Sea Fish Farms
}

\section{OPEN ACCESS}

Edited and reviewed by:

Axel Cloeckaert,

Institut National de la Recherche

Agronomique (INRA), France

${ }^{*}$ Correspondence:

Windi I. Muziasan

windi.muziasari@helsinki.fi

Marko Virta

marko.virta@helsinki.fi

Specialty section:

This article was submitted to

Antimicrobials, Resistance and

Chemotherapy,

a section of the journal

Frontiers in Microbiology

Received: 27 June 2017

Accepted: 25 July 2017

Published: 02 August 2017

Citation:

Muziasari WI, Pitkänen LK, Sørum H, Stedtfeld RD, Tiedje JM and Virta M (2017) Corrigendum: The Resistome of Farmed Fish Feces Contributes to

the Enrichment of Antibiotic

Resistance Genes in Sediments below

Baltic Sea Fish Farms.

Front. Microbiol. 8:1491.

doi: 10.3389/fmicb.2017.01491

\begin{abstract}
Windi I. Muziasari ${ }^{*}$, Leena K. Pitkänen ${ }^{1}$, Henning Sørum ${ }^{2}$, Robert D. Stedtfeld ${ }^{3}$, James M. Tiedje ${ }^{3}$ and Marko Virta ${ }^{1 *}$

${ }^{1}$ Department of Food and Environmental Sciences, University of Helsinki, Helsinki, Finland, ${ }^{2}$ Department of Food Safety and Infection Biology, Norwegian University of Life Sciences, Oslo, Norway, ${ }^{3}$ Department of Civil and Environmental Engineering, Center for Microbial Ecology, Michigan State University, Michigan, MI, USA
\end{abstract}

Keywords: rainbow trout, whitefish, class 1 integrons, transposons, mobile genetic elements, qPCR array, culture-independent method

\section{A corrigendum on}

The Resistome of Farmed Fish Feces Contributes to the Enrichment of Antibiotic Resistance Genes in Sediments below Baltic Sea Fish Farms

by Muziasari, W. I., Pitkänen, L. K., Sørum, H., Stedtfeld, R. D., Tiedje, J. M., and Virta, M. (2017). Front. Microbiol. 7:2137. doi: 10.3389/fmicb.2016.02137

In the original article, there was a mistake in Table 2 . Twenty of the 28 genes detected in the farmed fish intestinal contents as published. In the Table 2, the numbers of average relative abundance of the 20 genes to the $16 \mathrm{~S}$ rRNA gene were not correct. The corrected numbers of the gene abundances appears below. We apologize for this error and the error does not change the scientific conclusions of the article in any way.

Conflict of Interest Statement: The authors declare that the research was conducted in the absence of any commercial or financial relationships that could be construed as a potential conflict of interest.

Copyright $\odot 2017$ Muziasari, Pitkänen, Sørum, Stedtfeld, Tiedje and Virta. This is an open-access article distributed under the terms of the Creative Commons Attribution License (CC BY). The use, distribution or reproduction in other forums is permitted, provided the original author(s) or licensor are credited and that the original publication in this journal is cited, in accordance with accepted academic practice. No use, distribution or reproduction is permitted which does not comply with these terms. 
TABLE 2 | Twenty of the 28 genes detected in the farmed fish intestinal contents.

Classification of the antibiotics the genes confer resistance to

qPCR assay

Average relative abundance to the 16S rRNA gene

Fish intestinal contents (sampled in 2014)

Fish farm sediments (sampled in 2006-2012)

\begin{tabular}{|c|c|c|c|}
\hline Aminoglycoside & aadA1 & $2 \times 10^{-2}$ & $a_{3} \times 10^{-4}$ \\
\hline Aminoglycoside & aadA2-01 & $2 \times 10^{-2}$ & $a_{2} \times 10^{-4}$ \\
\hline Aminoglycoside & aadA2-02 & $2 \times 10^{-2}$ & $a_{4} \times 10^{-4}$ \\
\hline Aminoglycoside & $\operatorname{aadA2-03~}$ & $4 \times 10^{-2}$ & $a_{8} \times 10^{-4}$ \\
\hline Trimethoprim & dfrA1 & $6 \times 10^{-2}$ & $a_{3} \times 10^{-3}$ \\
\hline Trimethoprim & dfrA1-02 & $4 \times 10^{-2}$ & $b_{1} \times 10^{-3}$ \\
\hline Class 1 integron & intl1 & $6 \times 10^{-2}$ & $b_{3} \times 10^{-3}$ \\
\hline Other (Antiseptic) & qacE $\Delta 1-01$ & $1 \times 10^{-2}$ & $a_{5} \times 10^{-3}$ \\
\hline Other (Antiseptic) & qacE $\Delta 1-02$ & $1 \times 10^{-1}$ & $a_{3} \times 10^{-3}$ \\
\hline Sulfonamide & sul1 & $7 \times 10^{-2}$ & $b_{4} \times 10^{-3}$ \\
\hline Tetracycline & tet(32) & $3 \times 10^{-2}$ & $a_{1} \times 10^{-3}$ \\
\hline Tetracycline & tetM-01 & $1 \times 10^{-1}$ & $a_{3} \times 10^{-3}$ \\
\hline Tetracycline & tetM-02 & $9 \times 10^{-2}$ & $a_{2} \times 10^{-3}$ \\
\hline Tetracycline & tetM-03 & $4 \times 10^{-2}$ & $c_{1} \times 10^{-3}$ \\
\hline Tetracycline & tetO-01 & $2 \times 10^{-2}$ & $a_{2} \times 10^{-3}$ \\
\hline Tetracycline & tetW-01 & $4 \times 10^{-2}$ & $a_{4} \times 10^{-4}$ \\
\hline Transposon & tnpA-01 & $3 \times 10^{-2}$ & ${ }^{a} 6 \times 10^{-4}$ \\
\hline Transposon & tnpA-04 & $4 \times 10^{-2}$ & $a_{2} \times 10^{-4}$ \\
\hline Transposon & tnpA-06 & $5 \times 10^{-1}$ & $a_{1} \times 10^{-3}$ \\
\hline Transposon & tnpA-07 & $4 \times 10^{-2}$ & $a_{4} \times 10^{-3}$ \\
\hline
\end{tabular}

aMuziasari et al., 2016.

${ }^{b}$ Muziasari et al., 2014.

cTamminen et al., 2011.

$b, c$ The quantification of the genes used standard qPCR.

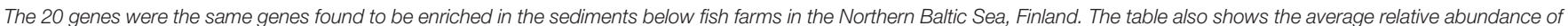

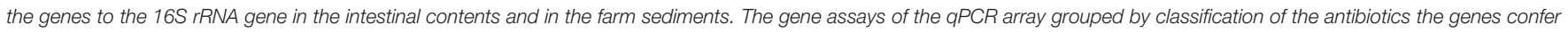
resistance to, class 1 integron and transposon. 